\title{
Plant growth-promoting rhizobacteria mediate induced systemic resistance in rice against bacterial leaf blight caused by Xanthomonas oryzae pv. oryzae
}

\author{
Chithrashree $^{\text {a }}$, A.C. Udayashankar ${ }^{\text {b }}$, S. Chandra Nayaka ${ }^{\text {b }}$, M.S. Reddy ${ }^{c}$, C. Srinivas ${ }^{\text {a,* }}$ \\ a Biocontrol Research Laboratory, Department of Studies in Microbiology and Biotechnology, Bangalore University, Jnana Bharathi Campus, Bangalore 560 056, Karnataka, India \\ ${ }^{\mathrm{b}}$ Department of Studies in Biotechnology, University of Mysore, Manasagangotri, Mysore 570 006, Karnataka, India \\ ${ }^{\mathrm{c}}$ Department of Entomology and Plant Pathology, 209 Life Sciences Bldg., Auburn University, AL 36849, USA
}

\section{A R T I C L E I N F O}

\section{Article history:}

Received 20 September 2010

Accepted 13 June 2011

Available online 28 June 2011

\section{Keywords:}

Bacterial leaf blight

Bacillus spp.

Defense enzymes

Plant growth-promoting rhizobacteria

Rice

Xanthomonas oryzae pv. oryzae

\begin{abstract}
A B S T R A C T
Seven Bacillus plant growth-promoting rhizobacteria spp. were evaluated for growth promotion and induced systemic resistance in rice against Xanthomonas oryzae pv. oryzae (Xoo). The identities of colonies of X. oryzae pv. oryzae grown on mXOS and PSA medium were confirmed by PCR employing specific primers TXTF and TXT4R. Among the seven strains tested as fresh suspensions, talc and sodium alginate formulations under laboratory and green house conditions, maximum germination of $86 \%$ was recorded after seed treatments with fresh suspension of Bacillus subtilis $\mathrm{GBO} 3$ followed by $85 \%$ germination treated with Bacillus pumilus SE34 in comparison to only $71 \%$ germination in the untreated controls. Similarly, the maximum vigor index of 1374 was obtained by seed treatment with fresh suspensions of $B$. subtilis strain GBO3 followed by treatments with strain SE34 with vigor index of 1323 in contrast to an index of only 834 observed in untreated controls. Among the treatments, seed treatments with fresh suspension of seven strains resulted in better germination and vigor assessments than talc based or sodium alginate formulations. Seed treatments with fresh suspension of strain SE34 gave 71\% protection, followed by B. subtilis GBO3 and B. pumilus T4 with $58 \%$ and $52 \%$ protection, respectively, compared to the untreated controls. Seed treatments with talc based formulation of SE34 gave 66\% protection, while GBO3 and T4 resulted in $52 \%$ and $50 \%$ protection, respectively, with similar formulation. Seed treatment with talc and sodium alginate formulations of strain SE34 gave 58\% protection followed by GBO3 with $40 \%$ protection. Seed treatment with fresh suspensions of strains SE34 and GBO3 followed by challenge inoculations with Xoo increased accumulation of phenylalanine ammonia lyase, peroxidase and polyphenol oxidase compared to untreated control seedlings. Thus, the results of the present study suggest that the PGPR strains used as fresh suspensions and powdered formulations may have commercial potential in plant growth promotion and in management of rice bacterial leaf blight disease.
\end{abstract}

(c) 2011 Elsevier Inc. All rights reserved.

\section{Introduction}

Rice (Oryza sativa L.) is the staple food for three fourths of the Indian population. In the global context, India stands first in area with 43.7 million hectares and second in production with 92.24 million metric tonnes (Viraktamath and Rani, 2008). Rice production has intensified to meet consumer demand. The concern to protect the agricultural environment is inevitable because of the harmful effects of excessive use of agrochemicals. Rice diseases have always had a significant impact on rice supply. Considering

Abbreviations: PAL, phenylalanine ammonia lyase; POX, peroxidase; PPO, polyphenol oxidase; CAT, catalase; PGPR, plant growth promoting rhizobacteria; PR proteins, pathogenesis-related proteins; PSA, peptone sucrose agar; BLB, bacterial leaf blight; ISR, induced systemic resistance; Xoo, Xanthomonas oryzae pv. oryzae; SA, salicylic acid; JA, jasmonic acid; CMC, carboxymethyl cellulose; cfu, colony forming units.

* Corresponding author. Fax: +91 08023219295.

E-mail address: srinivas_uom@rediffmail.com (C. Srinivas). the large rice production area in the world, even a conservative estimate of $1-5 \%$ annual loss would translate into thousands of tonnes of rice and billions of dollars lost. Thus, minimizing the occurrence of disease epidemics and reducing year-to-year losses are central to sustaining rice productivity (Mew et al., 2004).

Bacterial leaf blight (BLB) caused by Xanthomonas oryzae pv. oryzae (Xoo) is a major seed-borne pathogen of rice and is a threat to rice production in both temperate and tropical rice-growing regions, due to its high epidemic potential (Mew, 1987). BLB of rice causes considerable losses in all cultivars of rice in India, particularly in the Punjab state of India (Reddy, 1980).

Currently, the disease is managed through the use of resistant cultivars and systemic bactericides. However, the lack of durable resistance, existence of pathogenic variability, and concerns about chemical resistance has limited the potential of such strategies for managing the disease. Recently, an increasing desire to reduce the pesticides is seen through the attempts to develop integrated pest management approaches, where natural resources are put to 
maximum use. Hence host resistance is given priority in disease control strategy. Biological control through the use of plant growth-promoting bacteria is high on the list of potential alternative tactics (Nelson, 2004).

PGPR are free living, root colonizing bacteria that have beneficial effects on plants. They reduce disease severity and enhance yield of many crops (Liu et al., 1995; Murphy et al., 2000). In the context of the international concern for food and environmental quality, the use of PGPR has been applied to various crops to enhance growth, seedling emergence and crop yield, and some have been commercialized (Herman et al., 2008; Nayaka et al., 2009; Choong-Min et al., 2007; Saravanakumar et al., 2007; Murphy et al., 2003; Zhang et al., 2004). Rhizobial inoculants have also been reported to improve nutrient uptake, growth, seedling vigor and yield of rice (Biswas et al., 2000).

PGPR bring about disease suppression by various modes of action such as antagonism, competition for space and nutrients, and induction of systemic resistance (ISR) (Kumari and Srivastava, 1999). PGPR may mediate biological control indirectly by eliciting induced systemic resistance against a number of plant diseases (Jetiyanon and Kloepper, 2002). Application of some PGPR strains to seeds or seedlings has also been found to induce ISR in the treated plants (Kloepper et al., 1999). This phenomenon is known as induced systemic resistance and can be triggered by a variety of biotic and abiotic stimuli (Bostock, 2005). In addition, basal resistance responses that act at the site of pathogen infection, plants are also capable of developing a nonspecific resistance that is effective against pathogen attack.

Selected strains of nonpathogenic PGPR can reduce disease in above ground plant parts through the induction of a defense state that is commonly referred to as rhizobacteria-induced systemic resistance (Van Loon et al., 1998). Induced systemic resistance (ISR)-inducing PGPRs have also been demonstrated to enhance the plant's defense capacity by priming for potentiated expression of defense genes (Kim et al., 2004; Tjamos et al., 2005) strongly suggesting that priming is common feature of PGPR-mediated ISR. Ryu and his associates demonstrated that some PGPR can induce priming by the release of volatiles. For instance, Bacillus subtilis GBO3 induces a signaling pathway that is independent of salicylic acid (SA), jasmonic acid (JA) and the Npr1 gene (SA insensitive or nonexpresser of PR genes), yet it requires ethylene (Ryu et al., 2004). Priming offers an energy cost-efficient strategy, enabling the plant to react more effectively to any invader encountered by boosting infection-induced cellular defense responses (Becker and Conrath, 2007; Conrath et al., 2006).

The increased levels of defense related enzymes during ISR are known to play a crucial role in host resistance (Chen et al., 2000; Schneider and Ullrich, 1994; Ramamoorthy et al., 2002). In addition to improvement of plant growth, PGPR are directly involved in increased uptake of nitrogen, synthesis of phytohormones, phosphate solubilization and production of siderophores that chelate iron and make it available to the plant roots (Lalande et al., 1989; Bowen and Rovira, 1999).

Efforts have been made to use bacterial antagonists like Pseudomonas fluorescens in the management of bacterial leaf blight of rice (Vidhyasekaran et al., 2001). Babu et al. (2003) reported that treatment with acibenzolar-S-methyl (ASM) induced resistance to bacterial leaf blight in rice. Bacillus spp. including Bacillus amyloliquefaciens, B. subtilis, Bacillus pasteurii, Bacillus cereus, Bacillus pumilus, Bacillus mycoides, and Bacillus sphaericus have been reported to significantly reduce the incidence of disease on a diversity of hosts (Kloepper et al., 2004). Elicitation of ISR by these strains has been demonstrated in greenhouse or field trials on tomato (Solanum lycopersicum L.), bell pepper (Capsicum annuum L.), muskmelon (Cucumis melo L.), watermelon (Citrulus lanatus [Thunb.] Matsum. and Nakai), sugar beet (Beta vulgaris L.), tobacco (Nicotiana tabacum L.), Arabid- opsis spp., and cucumber (Cucumis sativus L.) against leaf-spotting fungal and bacterial pathogens, systemic viruses, a crown-rotting fungal pathogen, root-knot nematodes, and a stem-blight fungal pathogen as well as damping-off, blue mold, and late blight diseases (Kloepper et al., 2004). In most cases, Bacillus spp. that elicits ISR also elicits plant growth promotion (Kloepper et al., 2004).

The strains selected in the present study have shown to induce resistance against multiple plant diseases (Raupach and Kloepper, 2000; Jetiyanon and Kloepper, 2002; Niranjan-Raj et al., 2003a,b; Murphy et al., 2003; Choong-Min et al., 2007; Udayashankar et al., 2009). However, very few studies have been made on induced resistance in rice. Hence the present study was conducted to evaluate the effectiveness of seed treatment with fresh suspensions and their powdered formulations of selected PGPR Bacillus spp. for management of BLB of rice through ISR.

\section{Materials and methods}

\subsection{PGPR strains and inoculum preparation}

Seven PGPR strains (B. pumilus INR7, SE34 and T4; B. amyloliquefaciens IN937a, B. subtilis IN937b and GB03; Brevibacillus brevis IPC11) were used in the present study. These strains were obtained from Auburn University, Auburn, AL, USA (Courtesy: Prof. J.W. Kloepper and Prof. M.S. Reddy). The strains were stored in tryptic soy broth amended with glycerol $(20 \%)$ at $-70^{\circ} \mathrm{C}$ prior to use.

Bacterial cell suspensions were prepared by streaking the isolates onto tryptic soy agar and incubating at $27^{\circ} \mathrm{C}$ for $24 \mathrm{~h}$ to check the purity, then transferring single colonies onto tryptic soy agar plates. After $24 \mathrm{~h}$, the bacterial cells were harvested from plates in sterile distilled water and centrifuged at $8000 \mathrm{~g}$ for $5 \mathrm{~min}$ (REMI C-24, Bangalore, India). The pellets obtained were resuspended in sterile distilled water and again subjected to centrifugation, and the supernatants were discarded. The pellets were finally collected in sterile distilled water and cell populations were adjusted to $10^{8} \mathrm{cfu} \mathrm{ml}^{-1}$ as measured spectrophotometrically (Thompson, 1996).

\subsection{Host}

The seeds of the rice cv., IR-64, susceptible toX. oryzae pv. oryzae were obtained from National Seeds Corporation, Bangalore, India and were used throughout the study.

\subsection{Bacterial pathogen}

Rice seed samples and rice plants showing typical bacterial leaf blight symptoms were collected for isolation of $X$. oryzae pv. oryzae during a 2006-2007 field survey. The collected rice seed samples and diseased leaves were subjected to liquid assay for detection of $X$. oryzae pv. oryzae (Mortensen, 2005). From each rice seed sample collected 400 seeds or leaf materials were ground with autoclaved pestle and mortar, suspended in $200 \mathrm{ml}$ of sterile saline for $2 \mathrm{~h}$. The suspensions were serially diluted $4 \times 1: 10$ in test tubes. Aliquots of $0.05 \mathrm{ml}$ were spread onto mXOS (modified XOS agar; Di et al., 1991; Gnanamanickam et al., 1994) medium and incubated at $28 \pm 2{ }^{\circ} \mathrm{C}$ for $3-5$ days. X. oryzae pv. oryzae was confirmed by employing specific primers TXTF5'-GTCAAGCCAACTGTGTA-3' and TXT4R5'-CGTTCGGCACAGTTG-3' according to Sakthivel et al. (2001). The amplicons generated by PCR were ligated into pTZ57R/ $\mathrm{T}$ cloning vector using an InsTAclone ${ }^{\mathrm{TM}} \mathrm{PCR}$ cloning kit (Fermentas Life Sciences) according to the manufacturer's instructions, transformed into competent cells by the heat shock method. Recombinant plasmid DNA was isolated from overnight grown liquid cultures of selected clones using the Plasmid Mini Prep Kit (Sigma-Aldrich) or PCR products were directly sequenced. 
The pathogenicity of the isolated $X$. oryzae pv. oryzae was confirmed by clip inoculation. X. oryzae pv. oryzae was maintained on rice cultivar IR-64 in a greenhouse and on PSA (Agarwal et al., 1989; Sakthivel et al., 2001) and nutrient agar under laboratory conditions. Thirty-day-old rice plants grown in greenhouse with fully expanded leaves were clip inoculated with the sterile scissors dipped in bacterial suspension $\left(10^{8} \mathrm{cfu} \mathrm{m}^{-1}\right.$ ) (Kauffman et al., 1973). For inoculum preparation, the $36 \mathrm{~h}$ old bacterial cultures were multiplied on PSA for $48 \mathrm{~h}$, centrifuged at $5000 \mathrm{~g}$ for $10 \mathrm{~min}$ and the bacterial pellets were washed with sterile saline. Cell suspensions were adjusted to $10^{8} \mathrm{cfu} \mathrm{ml}^{-1}$ (Thompson, 1996).

\subsection{Mode of PGPR application}

All seven strains were used as fresh suspension and powdered formulations. Assays were conducted separately for each formulation tested. For fresh suspensions, seed of cv. IR-64 were surface sterilized with $2 \%$ sodium hypochlorite for $2 \mathrm{~min}$. Bacterization of the seed was achieved by soaking rice seeds in $10^{8} \mathrm{cfu} \mathrm{ml}^{-1}$ PGPR suspensions $(100 \mathrm{~g} / 500 \mathrm{ml})$, prepared as described earlier, and amended with $0.2 \%$ sterilized carboxymethyl cellulose (CMC) as a sticker. The suspensions were incubated at $26{ }^{\circ} \mathrm{C}$ in a rotary shaker at $150 \mathrm{rpm}$ for $6 \mathrm{~h}$ to facilitate attachment of bacterial cells to the seed coat. Later, the seed were allowed to dry in an incubator at $30^{\circ} \mathrm{C}$. The seeds treated with sterile distilled water amended with $\mathrm{CMC}$ and seeds soaked in distilled water alone served as controls.

PGPR in purified talc and sodium alginate powder formulations were prepared by aseptically mixing $400 \mathrm{ml}$ of the bacterial suspension, prepared as described above, with $1 \mathrm{~kg}$ of commercial talc powder (S.D. Fine Chemicals) and sodium alginate powder (HiMedia, Mumbai) separately. The purified talc and sodium alginate powder were autoclaved at $121{ }^{\circ} \mathrm{C}(115 \mathrm{psi}$ for $20 \mathrm{~min})$ on two consecutive days. This formulated mixture was mixed with $0.2 \% \mathrm{CMC}$ prior to treating seed. Surface-sterilized rice seed were mixed with the formulation at a rate of $10 \mathrm{~g} / \mathrm{kg}$ of seed. The seeds treated with sterile talc powder or sodium alginate amended with CMC and seeds treated with talc powder or sodium alginate alone served as controls.

\subsection{Effect of PGPR on seed germination and seedling vigor of rice under laboratory conditions}

The germination tests were carried out according to the paper towel method (ISTA, 2003) separately for fresh suspensions, talc and sodium alginate formulations. PGPR-treated seeds with fresh and powdered formulations and untreated controls were seeded onto paper towels. One hundred seeds were placed equidistantly on the germination paper presoaked in distilled water and covered with another presoaked paper towel, and rolled up along with polythene wrapping to prevent drying of towels. The rolled towels were incubated for 14 days at $24 \pm 1{ }^{\circ} \mathrm{C}$. After incubation, paper towels were unrolled and number of germinated seeds were counted and represented in percentage. The vigor index was calculated by using the formula as described by Baki and Anderson (1973). To assess vigor, the length of the root and shoot of an individual seedling was measured.

The vigor Index was calculated using the formula $\mathrm{VI}=$ (mean root length + mean shoot length) $\times$ germination (\%). The experiment consisted of four replicates of 100 seeds each and the entire experiment was repeated three times.

\subsection{Effect of PGPR on growth promotion of rice under greenhouse conditions}

Seeds treated with fresh cultures and formulations of PGPR strains along with untreated controls were sown separately in pots filled with sterilized soil, sand and manure at 1:1:1 ratio. Each pot received $25 \mathrm{ml}$ of $1 / 3(\mathrm{v} / \mathrm{v})$ strength Hoagland's solution once a week. Seedlings were raised in greenhouse conditions, watered daily and did not receive additional fertilization. At 30 days after seeding, seedling emergence and plant growth promoting activities (plant height, fresh weight and dry weight) were measured. Each treatment consisted of four replicates of 100 seeds each (25 seeds/pot) and the experiment was repeated three times.

\subsection{Effect of seed treatment with PGPR strains on bacterial leaf blight incidence of rice under greenhouse conditions}

Seed bacterization, sowing and seedlings were grown as described above Thirty-day-old-seedlings were clip inoculated with sterile scissors dipped in cultures $10^{8} \mathrm{cfu} \mathrm{ml}^{-1}$ of Xoo following the procedures described by Kauffman et al. (1973). The inoculated plants were covered for $24 \mathrm{~h}$ with a polythene bag, with care taken that the plants are not in direct contact with the bag. Seeds treated with distilled water $+0.2 \% \mathrm{CMC}$, seeds treated with talc $+0.2 \% \mathrm{CMC}$ and seeds treated with sodium alginate $+0.2 \%$ CMC served as control for fresh suspension, talc and sodium alginate formulations, respectively. Seeds treated with Bactomin (antibiotic; 2-bromonitropropane 1-3 diol) $2 \mathrm{~g} / \mathrm{kg}$ of seeds served as a positive control. In each pot, 15 plants were inoculated, and the disease incidence (\%) was recorded by counting the number of infected plants 30 days after inoculation. The experiment was repeated three times. The percent protection offered was calculated by formula, (control - treated)/control $\times 100$.

\subsection{Induction of defense enzymes by PGPR strains in rice against Xoo}

The two Bacillus spp. PGPR strains (B. pumilus SE34 and B. subtilis GBO3) which offered the highest levels of protection against BLB under greenhouse conditions were used to study induction of defense reaction in rice seedlings against Xoo infection in greenhouse conditions. PGPR were applied as seed treatment using fresh suspensions. Seed bacterization, sowing and seedlings were raised as described above. Thirty-day-old-seedlings were challenge inoculated with pure culture suspension of Xoo $\left(10^{8} \mathrm{cfu} \mathrm{m}^{-1}\right)$ by clip inoculation method as described earlier. The following treatments were included in the experiment: (1) seedlings raised from untreated seeds (control); (2) seedlings raised from untreated seeds and challenge inoculated with Xoo; (3) seedlings raised from bacterized seeds; and (4) seedlings raised from bacterized seeds and challenge inoculated with Xoo. For each treatment, 100 plants of four replicates were maintained ( 25 seedlings/pot). The experiment was repeated three times and samples for enzyme assay were collected separately during three repetitions.

Thirty-day-old-seedlings maintained in green house were used for defense enzymes studies. Plants were carefully uprooted without causing any damage to root and leaf tissues at different time intervals viz., $0,6,12,24,36,48,72$, and $96 \mathrm{~h}$ after challenge inoculation. There were eight pots per treatment with 25 seedlings/pot. Fresh seedlings were washed in running tap water, blot dried and homogenized with liquid nitrogen in a pre-chilled mortar and pestle. The homogenized plant tissues were used immediately or were stored in deep freezer $\left(-70^{\circ} \mathrm{C}\right)$ until used for biochemical analysis. Variation in activity of defense related enzymes, phenylalanine ammonia lyase (PAL; EC 4.3.1.5), peroxidase (POX; EC 1.11.1) and polyphenol oxidase (PPO; EC 1.14.18.1) was determined by enzyme assays according to Ross and Sederoff (1992), Hammerschmidt et al. (1982) and Mayer et al. (1965), respectively, and the enzyme activity was expressed as nmoles of cinnamic acid $\mathrm{min}^{-1} \mathrm{~g}$ protein ${ }^{-1}$ and change in absorbance $\mathrm{min}^{-1} \mathrm{mg}^{-1}$ of protein, respectively. Each of the enzyme assays were repeated three times. 


\subsection{Protein estimation}

Protein contents of the extracts for all estimated enzymes were determined by using the standard procedure of Lowry et al. (1951) using bovine serum albumin (BSA) (Sigma, USA) as standard.

\subsection{Statistical analysis}

Data from repeated laboratory and green house studies were analyzed separately and subjected to analysis of Variance (ANOVA) (SPSS Software). The significance of effects of PGPR treatments was determined by the magnitude of $F$ value $(P=0.05)$. Treatment means were separated by Duncan's multiple range test (DMRT).

\section{Results}

\subsection{Pathogen, source, and inoculation}

Twenty-three rice seed samples and twelve leaf samples were collected during field survey for isolation of $X$. oryzae pv. oryzae (data not shown). In surveyed areas, rice plants with typical BLB symptoms viz., leaf blight, wilting (Kresek) and pale yellowing of leaves were collected for isolation of $X$. oryzae pv. oryzae. The leaf blight symptoms appeared as yellow to white water-soaked stripes along the margins of the infected leaves (Fig. 1). Kresek is a strong systemic infection in which leaves or entire plants wilt and die during the seedling and early tillering stage. Among 23 seed samples and 12 leaf samples subjected to liquid assay method for detection of Xoo, 12 seed samples and three leaf samples recorded small, shiny with light pink centered colonies on mXOS medium. The suspected colonies were sub-cultured on NBY medium and the identity of the pathogen was confirmed by PCR by specific primers targeting the insertion sequence element IS113 of 'tnpX1' gene. The $964 \mathrm{bp}$ amplicon was generated in seven isolates collected from seed samples and three isolates from leaf samples (data not shown). X. oryzae pv. oryzae insertion sequence element IS113 of 'tnpX1' gene of 'putative transposase' product has been deposited in the GenBank (NCBI, EMBL, and DDBJ) via Accession No. GU982970. The nucleotide blast analysis of the cloned fragment closely matched (99\% homology) with X. oryzae pv. oryzae NCBI Accession No. CP000967, X. oryzae pv. oryzae PXO99A, com-

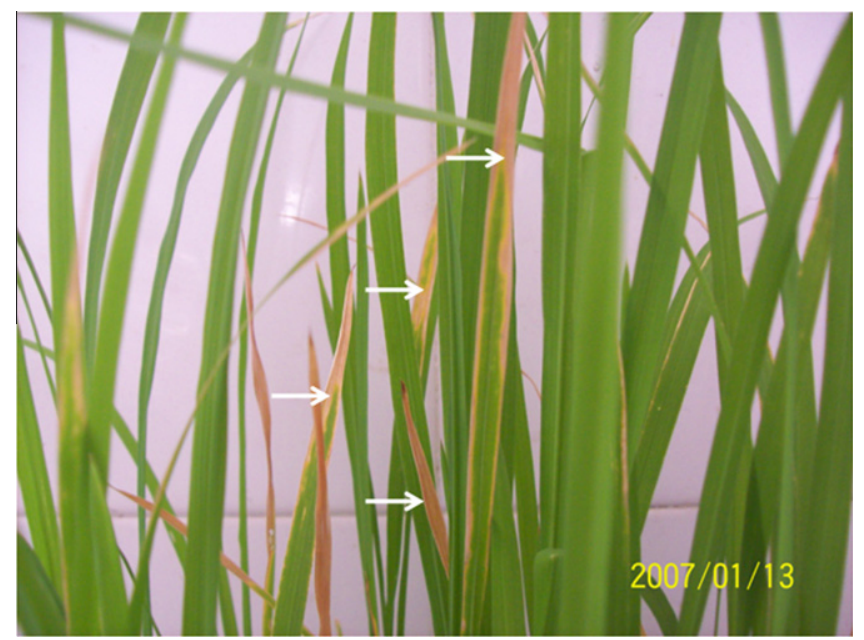

Fig. 1. Seed-borne bacterial leaf blight symptoms on rice caused by Xanthomonas oryzae pv. oryzae. Lesions consist of yellow to white water-soaked stripes along the margins of the infected leaves under green house conditions. Arrows indicate progressive development of symptoms. (For interpretation of the references to color in this figure legend, the reader is referred to the web version of this article.) plete genome. All the ten Xoo isolates positive in PCR produced typical BLB symptoms 14 days after inoculation thus confirming the pathogenicity of the Xoo isolates (Fig. 2).

\subsection{Effect of PGPR on seed germination and seedling vigor of rice under laboratory conditions}

None of the PGPR strains tested as fresh suspension or powdered formulations had any phytotoxic effect on rice seeds/seedlings. The percent germination of rice seeds treated with fresh suspension of different PGPR strains ranged from $77 \%$ to $86 \%$. The percent seed germination in the talc and sodium alginate treatment was between $75 \%$ and $82 \%$ and $74 \%$ and $79 \%$, respectively. The percent germination of control seeds without PGPR treatment was between $70 \%$ and $71 \%$. The vigor index of seedlings ranged from 1022 to 1374 for seeds treated with fresh suspensions, 1012 to 1309 for seeds treated with talc formulations and 996 to 1219 for seeds treated with sodium alginate formulations, compared with 834-850 in the control (Table 1). Among the seven PGPR strains tested, the highest germination of $86 \%$ and maximum vigor index of 1374 was recorded for seeds treated with fresh suspensions of GBO3 followed by SE34 with germination of $85 \%$ and vigor index of 1323. Similarly highest germination and vigor index was also obtained for seeds treated with talc and sodium alginate formulations of GBO3 and SE34 (Table 1).

\subsection{Effect of PGPR on growth promotion of rice under greenhouse conditions}

In general, all the PGPR strains tested as fresh suspensions and powdered formulations showed positive growth responses among all parameters recorded under greenhouse conditions compared with the non-bacterized controls. Specifically all the strains enhanced seed emergence and seedling height compared with the untreated control. The highest germination of $86 \%$ and $85 \%$ was resulted from seeds treated with fresh suspension of SE34 and GBO3 and similar results were obtained with the talc and sodium alginate formulations compared with untreated control (70\%) (Table 2). Similarly seed treatment of PGPR strains SE34 and GBO3 with fresh suspensions as well as powdered formulations increased plant height, fresh weight and dry weight over respective controls (Table 3).

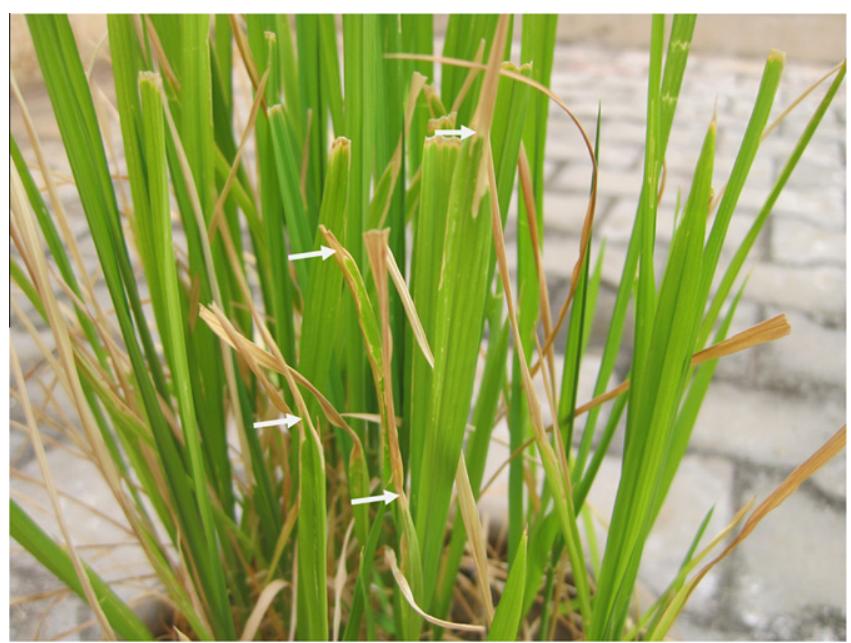

Fig. 2. Pathogenicity test: thirty-day-old-seedlings were challenge inoculated with pure suspensions of Xanthomonas oryzae pv. oryzae by clip inoculation produced typical bacterial blight symptoms. Arrows indicate progressive development of BLB symptoms. 
Table 1

Effect of seed treatment with fresh suspensions and talc formulations of PGPR strains on seed germination and seedling vigor of rice. ${ }^{\mathrm{A}}$

\begin{tabular}{|c|c|c|c|c|c|c|}
\hline \multirow[t]{2}{*}{ Treatment } & \multicolumn{3}{|c|}{ Germination (\%) } & \multicolumn{3}{|l|}{ Vigor index } \\
\hline & Fresh $^{\mathrm{B}}$ & Talc $^{\mathrm{C}}$ & Sodium alginate ${ }^{C}$ & Fresh $^{\mathrm{B}}$ & Talc $^{\mathrm{C}}$ & Sodium alginate ${ }^{c}$ \\
\hline Untreated control & $71 \pm 1.3^{\mathrm{d}}$ & $71 \pm 2^{d}$ & $70 \pm 0.9^{d}$ & $834 \pm 52^{d}$ & $850 \pm 43^{\mathrm{e}}$ & $849 \pm 8^{e}$ \\
\hline Bacillus pumilus INR7 & $79 \pm 1.2^{\mathrm{c}}$ & $76 \pm 1.2^{\mathrm{bc}}$ & $76 \pm 0.9^{\mathrm{bc}}$ & $1144 \pm 42^{b}$ & $1081 \pm 30^{\mathrm{cd}}$ & $1025 \pm 14^{\mathrm{cd}}$ \\
\hline Bacillus pumilus SE34 & $85 \pm 0.9^{\mathrm{ab}}$ & $82 \pm 0.9^{\mathrm{a}}$ & $79 \pm 0.6^{\mathrm{a}}$ & $1323 \pm 7^{\mathrm{a}}$ & $1232 \pm 25^{b}$ & $1130 \pm 9^{b}$ \\
\hline Bacillus subtilis GBO3 & $86 \pm 0.9^{a}$ & $82 \pm 1.2^{\mathrm{a}}$ & $79 \pm 0.6^{\mathrm{a}}$ & $1374 \pm 24^{\mathrm{a}}$ & $1309 \pm 13^{a}$ & $1219 \pm 14^{\mathrm{a}}$ \\
\hline Bacillus subtilis IN937b & $78 \pm 0.9^{d}$ & $77 \pm 0.6^{\mathrm{bc}}$ & $75 \pm 0.6^{\mathrm{c}}$ & $1077 \pm 16^{\mathrm{bc}}$ & $1012 \pm 26^{d}$ & $1000 \pm 19^{d}$ \\
\hline Brevibacillus brevis IPC11 & $82 \pm 0.6^{\mathrm{bc}}$ & $79 \pm 0.6^{\mathrm{ab}}$ & $76 \pm 0.9^{\mathrm{bc}}$ & $1130 \pm 26^{b}$ & $1082 \pm 17^{\mathrm{cd}}$ & $1037 \pm 17^{\mathrm{cd}}$ \\
\hline Bacillus pumilus $\mathrm{T} 4$ & $79 \pm 0.7^{\mathrm{cd}}$ & $78 \pm 0.9^{\mathrm{bc}}$ & $76 \pm 0.6^{\mathrm{bc}}$ & $1126 \pm 37^{b}$ & $1097 \pm 17^{c}$ & $1046 \pm 18^{c}$ \\
\hline Bacillus amyloliquefaciens IN937a & $77 \pm 0.7^{d}$ & $75 \pm 0.3^{c}$ & $74 \pm 0.6^{c}$ & $1022 \pm 7^{c}$ & $1017 \pm 6^{\mathrm{d}}$ & $996 \pm 10^{\mathrm{d}}$ \\
\hline Bactomin & $76 \pm 1.2^{\mathrm{d}}$ & $77 \pm 1.0^{\mathrm{bc}}$ & $74 \pm 1.0^{c}$ & $995 \pm 11^{\mathrm{c}}$ & $1002 \pm 21^{d}$ & $1015 \pm 27^{d}$ \\
\hline
\end{tabular}

A Values are the means \pm SE (standard error) from three repeated experiments with four replications of 100 seeds each. Means followed by the same letter ( $\mathrm{s}$ ) in a column do not differ significantly according to Duncan's multiple range test at $P=0.05$.

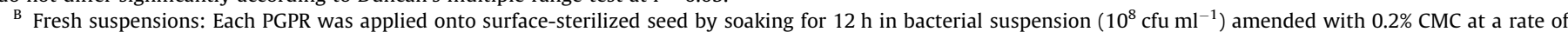
$5 \mathrm{ml} / \mathrm{g}$ of seed prior to seeding. Control: seeds soaked in sterile distilled water amended with $0.2 \%$ CMC.

$\mathrm{C}$ Talc and sodium alginate formulations: surface-sterilized seeds were treated with powdered formulations of PGPR amended with $0.2 \% \mathrm{CMC}$ at the rate of $10 \mathrm{~g} / \mathrm{kg}$ of seeds Control: seed soaked in sterile distilled water amended with $0.2 \%$ CMC and sterile carrier (talc or sodium alginate) material.

Table 2

Effect of seed treatments with fresh suspensions of PGPR strains on growth of rice seedlings 30 days after seeding under greenhouse conditions. ${ }^{\mathrm{A}}$

\begin{tabular}{|c|c|c|c|c|}
\hline Treatment $^{\mathrm{B}}$ & Seedling emergence (\%) & Plant height $(\mathrm{cm})$ & Fresh weight (g/seedling) & Dry weight (g/seedling) \\
\hline Untreated control & $70 \pm 0.6^{c}$ & $20.3 \pm 0.6^{\mathrm{e}}$ & $0.22 \pm 0.009^{d}$ & $0.021 \pm 0.0005^{c}$ \\
\hline Bacillus pumilus INR7 & $81 \pm 2.0^{\mathrm{b}}$ & $28 \pm 0.5^{c}$ & $0.27 \pm 0.005^{\mathrm{bc}}$ & $0.028 \pm 0.001^{\mathrm{b}}$ \\
\hline Bacillus pumilus SE34 & $86 \pm 1.5^{\mathrm{a}}$ & $31.2 \pm 0.4^{\mathrm{a}}$ & $0.29 \pm 0.009^{\mathrm{b}}$ & $0.035 \pm 0.002^{\mathrm{a}}$ \\
\hline Bacillus subtilis GBO3 & $85 \pm 0.8^{a}$ & $32.6 \pm 0.5^{\mathrm{a}}$ & $0.31 \pm 0.009^{a}$ & $0.037 \pm 0.001^{\mathrm{a}}$ \\
\hline Bacillus subtilis IN937b & $78 \pm 1.5^{\mathrm{b}}$ & $25.8 \pm 0.6^{\mathrm{d}}$ & $0.26 \pm 0.005^{c}$ & $0.03 \pm 0.001^{\mathrm{b}}$ \\
\hline Brevibacillus brevis IPC11 & $81 \pm 0.7^{b}$ & $26.5 \pm 0.3^{\mathrm{cd}}$ & $0.26 \pm 0.006^{c}$ & $0.027 \pm 0.003^{b}$ \\
\hline Bacillus pumilus $\mathrm{T} 4$ & $79 \pm 1.5^{\mathrm{b}}$ & $29.6 \pm 0.4^{\mathrm{b}}$ & $0.29 \pm 0.001^{\mathrm{b}}$ & $0.029 \pm 0.0004^{\mathrm{b}}$ \\
\hline Bacillus amyloliquefaciens IN937a & $79 \pm 1.5^{\mathrm{b}}$ & $26.6 \pm 0.7^{\mathrm{cd}}$ & $0.27 \pm 0.004^{\mathrm{c}}$ & $0.028 \pm 0.0007^{\mathrm{b}}$ \\
\hline Bactomin & $76 \pm 0.6^{b}$ & $26.1 \pm 1.0^{\mathrm{d}}$ & $0.27 \pm 0.012^{c}$ & $0.031 \pm 0.0009^{b}$ \\
\hline
\end{tabular}

A Mean \pm SE (standard error) followed by the same letter do not differ significantly according to Duncan's multiple range test at $P=0.05$.

в Each PGPR was applied onto surface-sterilized seed by soaking for $12 \mathrm{~h}$ in bacterial suspension $\left(10^{8} \mathrm{cfu} \mathrm{ml}^{-1}\right)$ amended with $0.2 \% \mathrm{CMC}$ at a rate of $5 \mathrm{ml} / \mathrm{g}$ of seed prior to seeding.

Table 3

Effect of seed treatments with powdered formulations of PGPR (Bacillus spp.) on growth on rice thirty days after seeding under greenhouse conditions. ${ }^{\mathrm{A}}$

\begin{tabular}{|c|c|c|c|c|c|c|c|c|}
\hline \multirow[t]{2}{*}{ Treatment $^{B}$} & \multicolumn{2}{|c|}{ Seedling emergence (\%) } & \multicolumn{2}{|c|}{ Plant height $(\mathrm{cm})$} & \multicolumn{2}{|c|}{ Fresh weight (g/seedling) } & \multicolumn{2}{|c|}{ Dry weight (g/seedling) } \\
\hline & Talc & $\begin{array}{l}\text { Sodium } \\
\text { alginate }\end{array}$ & Talc & $\begin{array}{l}\text { Sodium } \\
\text { alginate }\end{array}$ & Talc & $\begin{array}{l}\text { Sodium } \\
\text { alginate }\end{array}$ & Talc & Sodium alginate \\
\hline Untreated control & $71 \pm 1.0^{\mathrm{c}}$ & $71 \pm 0.7^{\mathrm{d}}$ & $21.4 \pm 0.3^{\mathrm{d}}$ & $21.8 \pm 0.36^{c}$ & $0.22 \pm 0.0076^{\mathrm{e}}$ & $0.21 \pm 0.01^{\mathrm{d}}$ & $0.02 \pm 0.0001 \mathrm{e}$ & $0.022 \pm 0.0009^{\mathrm{e}}$ \\
\hline Bacillus pumilus INR7 & $80 \pm 0.9^{b}$ & $78 \pm 2.0^{\mathrm{bc}}$ & $25.6 \pm 0.34^{c}$ & $24.5 \pm 0.24^{\mathrm{b}}$ & $0.25 \pm 0.0035^{d}$ & $0.25 \pm 0.004^{c}$ & $0.027 \pm 0.0003^{\mathrm{cd}}$ & $0.026 \pm 0.0002^{\mathrm{cd}}$ \\
\hline Bacillus pumilus SE34 & $85 \pm 0.9^{a}$ & $82 \pm 0.7^{\mathrm{a}}$ & $28 \pm 0.28^{\mathrm{a}}$ & $25.5 \pm 0.27^{\mathrm{ab}}$ & $0.28 \pm 0.0052^{\mathrm{ab}}$ & $0.27 \pm 0.002^{\mathrm{ab}}$ & $0.033 \pm 0.0015^{b}$ & $0.03 \pm 0.0003^{\mathrm{b}}$ \\
\hline Bacillus subtilis GBO3 & $83 \pm 0.9^{a}$ & $81 \pm 1.0^{\mathrm{ab}}$ & $27.3 \pm 0.32^{\mathrm{a}}$ & $25.9 \pm 0.32^{\mathrm{a}}$ & $0.3 \pm 0.002^{\mathrm{a}}$ & $0.27 \pm 0.007^{\mathrm{a}}$ & $0.036 \pm 0.0006^{\mathrm{a}}$ & $0.033 \pm 0.0006^{\mathrm{a}}$ \\
\hline Bacillus subtilis IN937b & $78 \pm 1.2^{\mathrm{b}}$ & $76 \pm 1.5^{\mathrm{bc}}$ & $25.6 \pm 0.33^{\mathrm{bc}}$ & $24.7 \pm 0.33^{\mathrm{b}}$ & $0.25 \pm 0.0035^{d}$ & $0.25 \pm 0.001^{\mathrm{bc}}$ & $0.029 \pm 0.0003^{c}$ & $0.027 \pm 0.0003^{c}$ \\
\hline Brevibacillus brevis IPC11 & $78 \pm 0.6^{\mathrm{b}}$ & $75 \pm 0.3^{c}$ & $24.5 \pm 0.25^{c}$ & $22.7 \pm 0.51^{\mathrm{c}}$ & $0.26 \pm 0.0078^{\mathrm{cd}}$ & $0.24 \pm 0.002^{c}$ & $0.026 \pm 0.0003^{d}$ & $0.026 \pm 0.0004^{\mathrm{d}}$ \\
\hline Bacillus pumilus $\mathrm{T} 4$ & $79 \pm 0.9^{b}$ & $76 \pm 1.3^{c}$ & $26 \pm 0.5^{\mathrm{b}}$ & $25.6 \pm 0.3^{\mathrm{ab}}$ & $0.27 \pm 0.0014^{\mathrm{bc}}$ & $0.26 \pm 0.006^{\mathrm{abc}}$ & $0.028 \pm 0.0001^{\mathrm{c}}$ & $0.027 \pm 0.0006^{\mathrm{cd}}$ \\
\hline $\begin{array}{l}\text { Bacillus amyloliquefaciens } \\
\text { IN937a }\end{array}$ & $78 \pm 0.9^{\mathrm{b}}$ & $75 \pm 0.4^{\mathrm{c}}$ & $27.5 \pm 0.56^{\mathrm{a}}$ & $25.1 \pm 0.47^{\mathrm{ab}}$ & $0.26 \pm 0.0013^{\mathrm{cd}}$ & $0.26 \pm 0.009^{\mathrm{abc}}$ & $0.027 \pm 0.0003^{\mathrm{cd}}$ & $0.026 \pm 0.0002^{\mathrm{cd}}$ \\
\hline Bactomin & $76 \pm 0.9^{b}$ & $77 \pm 1.2^{\mathrm{bc}}$ & $26.3 \pm 0.54^{\mathrm{b}}$ & $25.3 \pm 0.9^{\mathrm{ab}}$ & $0.26 \pm 0.004^{\mathrm{cd}}$ & $0.26 \pm 0.009^{\mathrm{abc}}$ & $0.03 \pm 0.0012^{c}$ & $0.026 \pm 0.0002^{\mathrm{cd}}$ \\
\hline
\end{tabular}

A Means \pm SE (standard error) followed by the same letter do not differ significantly according to Duncan's multiple range test at $P=0.05$

B Surface sterilized seeds were treated with powdered formulations of PGPR amended with $0.2 \%$ CMC at the rate of $10 \mathrm{~g} / \mathrm{kg}$ of seed prior to seeding.

\subsection{Effect of seed treatment with PGPR strains on bacterial leaf blight incidence of rice under greenhouse conditions}

Varied degrees of protection (ranging from 23\% to 71\%) against bacterial leaf blight disease were induced by PGPR strains applied as both fresh suspensions and powdered formulations. When the test bacteria were applied as fresh suspensions, lowest disease incidence of $22 \%$ ( $71 \%$ protection) resulted with the strain SE34 followed by GBO3 and T4, which resulted in $31 \%$ and $37 \%$ of bacterial leaf blight incidence ( $58 \%$ and $52 \%$ protection), respectively (Table 4). Among the powdered formulation, talc formulation treatment with strain SE34 resulted in 26\% disease incidence (66\% protection) followed by GBO3 and T4 with $37 \%$ and $38 \%$ blight incidence (52\% and $50 \%$ protection), respectively. Similarly sodium alginate formulation treatment with strain SE34 and GBO3 resulted in lower disease incidence of $31 \%$ and $44 \%$ (58\% and $40 \%$ protection) followed by T4 with $39 \%$ bacterial leaf blight (39\% protection), respectively in comparison with the non-bacterized controls where the disease incidence was ranged from $75 \%$ to $76 \%$ (Table 4 ). The lowest incidence of BLB (11.2\% to 11.8\%) was recorded with Bactomin treatment.

\subsection{Induction of defense enzymes by PGPR strains in rice against Xoo}

Studies on induction of defense enzymes revealed that upon pathogen challenge in bacterized rice plants, PAL activity started 
Table 4

Effect of seed treatments with fresh suspensions and powdered formulations of PGPR strains on bacterial leaf blight incidence of rice grown under greenhouse conditions.

\begin{tabular}{llll}
\hline Treatment & \multicolumn{3}{l}{ Bacterial leaf blight incidence (\%) } \\
\cline { 2 - 4 } & Fresh $^{\mathrm{B}}$ & Talc $^{\mathrm{C}}$ & $\begin{array}{l}\text { Sodium } \\
\text { alginate }^{\mathrm{C}}\end{array}$ \\
\hline Untreated control & $75^{\mathrm{a}}$ & $76.3^{\mathrm{a}}$ & $75.3^{\mathrm{a}}$ \\
Bactomin & $11.3^{\mathrm{e}}$ & $11.2^{\mathrm{f}}$ & $11.8^{\mathrm{f}}$ \\
Bacillus pumilus INR7 & $50.7^{\mathrm{b}}(32)$ & $54.3^{\mathrm{b}}$ & $58.3^{\mathrm{b}}(23)$ \\
& & $(29)$ & \\
Bacillus pumilus SE34 & $22^{\mathrm{f}}(71)$ & $26^{\mathrm{e}}(66)$ & $31.4^{\mathrm{e}}(58)$ \\
Bacillus subtilis GBO3 & $31.3^{\mathrm{e}}(58)$ & $36.7^{\mathrm{d}}$ & $44.9^{\mathrm{d}}(40)$ \\
& & $(52)$ & \\
Bacillus subtilis IN937b & $40.2^{\mathrm{cd}}$ & $48^{\mathrm{c}}(37)$ & $51^{\mathrm{c}}(32)$ \\
Brevibacillus brevis IPC11 & $(46)$ & & \\
Bacillus pumilus T4 & $44^{\mathrm{c}}(41)$ & $46^{\mathrm{c}}(40)$ & $51.3^{\mathrm{c}}(32)$ \\
Bacillus amyloliquefaciens & $35.7^{\mathrm{de}}$ & $37.5^{\mathrm{d}}$ & $45.7^{\mathrm{d}}(39)$ \\
$\quad$ IN937a & $(52)$ & $(50)$ & \\
\hline
\end{tabular}

A Percentage of bacterial leaf blight is the mean of three repeated experiments. Means followed by the same letter (s) in a column do not differ significantly according to Duncan's multiple range test at $P=0.05$. Figures in parentheses represent percentage protection offered.

${ }^{B}$ Fresh suspensions: each PGPR was applied onto surface-sterilized seed by soaking for $12 \mathrm{~h}$ in bacterial suspension amended with $0.2 \% \mathrm{CMC}$ at rate of $5 \mathrm{ml} / \mathrm{g}$ of seed prior to seeding.

C Talc and sodium alginate formulations: surface sterilized seed were treated with powdered formulations of PGPR amended with $0.2 \% \mathrm{CMC}$ at a rate of $10 \mathrm{~g} / \mathrm{kg}$ of seeds.

to increase $6 \mathrm{~h}$ post pathogen inoculation and reached maximum on the $36 \mathrm{~h}$ and $48 \mathrm{~h}$ in plants treated with B. pumilus SE34 and B. subtilis GB03, respectively. Similarly, rice plants inoculated with the pathogen alone recorded slight increase in activity of PAL, but the induction of activity was observed for 24-48 h, thereafter declined gradually. Rice plants treated with $B$. pumilus SE34 and $B$. subtilis GB03 isolates alone also had significantly higher PAL (14.6 $\mathrm{n}$ moles of trans-cinnamic acid) compared to untreated control (11.6 nmol of trans-cinnamic acid) but the activity was less compared to challenge inoculated plants $(30.9 \mathrm{nmol}$ of transcinnamic acid) (Fig. 3A). POX activity was also increased in Bacillus isolates treated plants challenged with pathogen. The maximum activity was observed at $48 \mathrm{~h}$ in both B. pumilus SE34 and B. subtilis GB03 treated plants after challenge inoculation and the activity was maintained at higher levels throughout the experimental period. Plants inoculated with pathogen alone had comparatively less POX activity (Fig. 3B). A similar pattern of increased activity of PPO was observed in bacterized rice plants challenged with pathogen and the activity reached maximum on the 36 and $48 \mathrm{~h}$, in B. pumilus SE34 and B. subtilis GB03 treated plants, respectively after challenge inoculation with Xoo (Fig. 3C).

\section{Discussion}

Our results demonstrate the efficacy of PGPR in promoting growth and inducing resistance to bacterial leaf blight of rice under greenhouse conditions. PGPR are well known inducers of disease resistance and some strains are effective against a broad spectrum of plant pathogens in a number of crop species. PGPR can promote plant growth directly or indirectly. Indirect effects are related to production of metabolites, such as antibiotics, that decrease the growth of phytopathogens and other deleterious microorganisms (Silo-Suh et al., 1994; Raajimakers et al., 2002). Direct effects are dependent on production of plant growth regulators. Use of PGPR appears to favor seedling production, mainly through direct growth promotion, disease control and induced systemic resistance (Kloepper, 1993; Ramamoorthy et al., 2001).
Several researchers have successfully employed Bacillus species to control disease development. The bacterial spot disease caused by Xanthomonas axonopodis pv. vesicatoria was successfully controlled by using three Bacillus strains isolated from rhizosphere soil of pepper (C. annuum L.) grown in greenhouses and fields of Turkey. The bacterial spot disease development decreased by $11-62 \%$ and $38-67 \%$ in pepper plants inoculated with the Bacillus strains alone and in combination, respectively, in greenhouse and field experiments. In addition, stem diameter, root elongation, root dry weight, shoot dry weight, and yield increased in response to the treatments in the field experiment (Mustafa et al., 2008). In the present study, all the Bacillus strains tested reduced the incidence of bacterial leaf blight, lesion length and plant wilting in PGPR treated plants in comparison to control plants. Among the seven strains of Bacillus spp., one strain of B. subtilis (GBO3) and two strains of B. pumilus (SE34 and T4) showed higher levels of disease suppression when applied as seed treatments as fresh suspensions or powdered formulations (when applied at the rate of $10 \mathrm{~g} / \mathrm{kg}$ of seeds). The strain SE34 offered the highest level of protection of $71 \%$ against Xoo followed by GBO3 with $58 \%$ protection when seeds were treated with fresh suspensions. Strains SE34 and GBO3 were unique in that, apart from showing reduction of disease incidence, they also were the best growth promoters. The PGPR treated Xoo inoculated plants did not show wilting or death.

The reduction in disease incidence reflected on plant growth. Plant height and total biomass of treated plants were greater compared with non treated ones. These results are relatively similar to those obtained by Bai et al. (2003); they reported that three Bacillus strains, B. subtilis NEB4, NEB5 and Bacillus thuringiensis NEB17 provided increase in nodule number, nodule weight, shoot weight, root weight, total biomass, total nitrogen and grain yield of soybean plants. Raupach and Kloepper (2000) reported that seed treatment of cucumber with $B$. amyloliquefaciens IN937a and $B$. subtilis GBO3, resulted in significant increases in plant growth and reductions in disease severity. The present investigation reveals that under in vitro conditions, seed treatment with PGPR strains improves seed germination, seedling vigor, seedling emergence and seedling stand over the control. Similar improvement of seed germination parameters by rhizobacteria has been reported in cereals such as sorghum (Raju et al., 1999) and pearl millet (Niranjan-Raj et al., 2003a,b).

Systemic resistance triggered in the plant by rhizobacteria is referred to as rhizobacterial mediated ISR (Van Loon et al., 1998). ISR is brought about by PGPR'S through fortification of the physical and mechanical strength of the host leading to the synthesis of defense chemicals against the challenge pathogen. Prior application of $P$. fluorescens as seed treatment induces various defense mechanisms in the plants (Chen et al., 2000). Ryu et al. (2003) reported that Bacillus strains T4 and SE34 elicited ISR against two different pathovars of Pseudomonas syringae (pvs. tomato and maculicola). Strains IN937 and GBO3 did not elicit protection against either pathovars, although they demonstrated elicitation of ISR against other host-pathogen systems.

Induced systemic resistance in rice seedling is augmented by increased activities of various defense-related enzymes and chemicals in response to infection by pathogen. Growing body of evidence reports that, systemic protection against various rice pathogens resulting from ISR elicited by, among others, Pseudomonas spp. (Nandakumar et al., 2001), Bacillus (Jayraj et al., 2004) and Serratia strains (Someya et al., 2005). However, in most if not all cases, still very little is known about the basic mechanisms governing this ISR response. Serratia plymuthica IC1270 induced systemic resistance against various rice pathogens with different modes of infection (De-Vleesschauwer et al., 2009). They also demonstrated that rice plants of which the roots were colonized by the Pseudomonas aeruginosa 7NSK2 developed an enhanced defensive capacity 
………... T1

……...... T2

A. Phenylalanine ammonia lyase

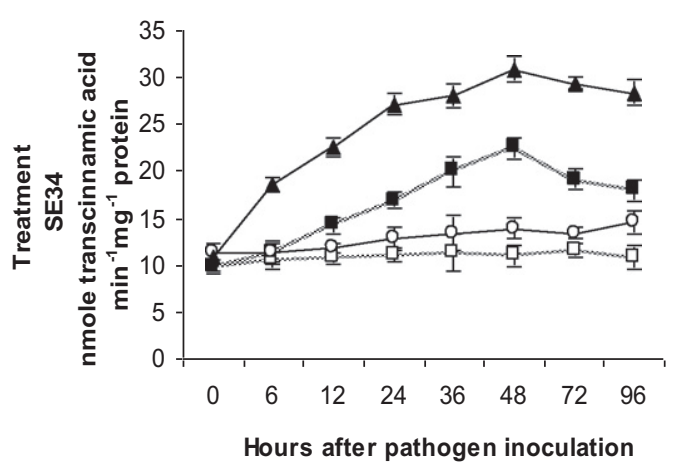

B. Peroxidase activity

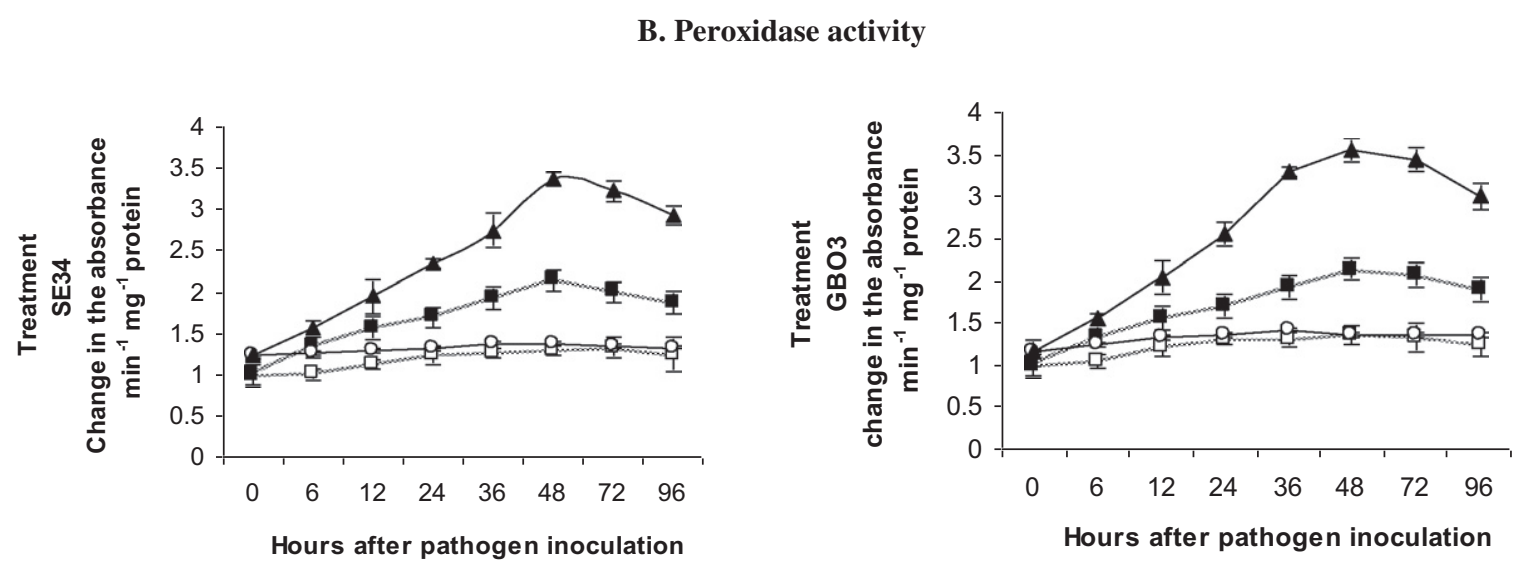

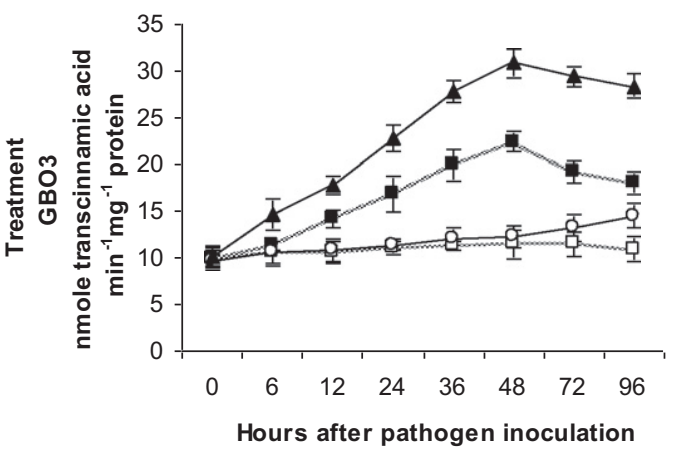

Hours after pathogen inoculation

C. Polyphenol oxidase activity
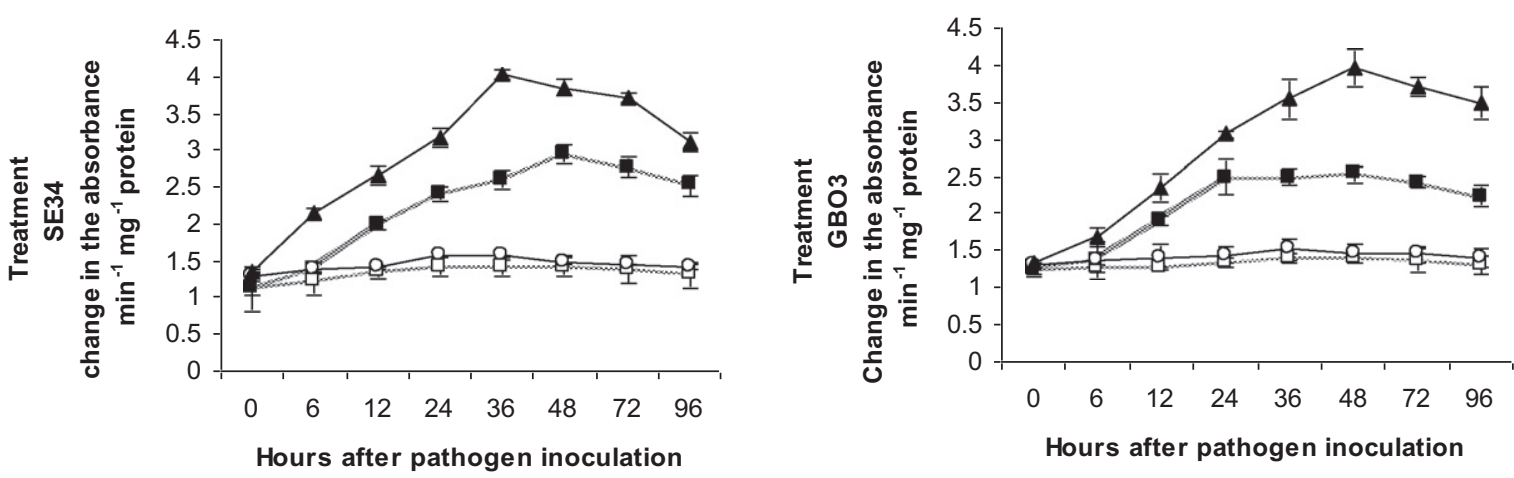

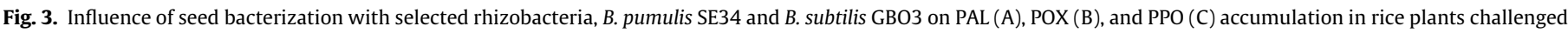

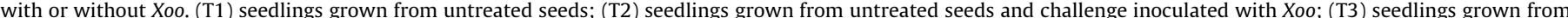

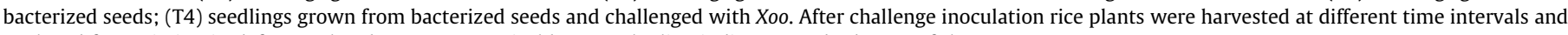
analyzed for variation in defense related enzymes. Vertical bars on the line indicate standard error of the means.

against infection with Magnaporthe oryzae. De-Vleesschauwer et al. (2008), reported that colonization of rice roots with pseudobactinproducing WCS374r bacteria increases cellular defense response, resulting in an enhanced level of resistance against the leaf blast pathogen, M. oryzae, and different resistance strategy was found to be associated with priming for a diverse set of hypersensitive response independent cellular defense.

PGPR mediated systemic resistance is often associated with the onset of defense mechanisms by expression of various defense related enzymes such as $\beta$-1-3-glucanase, chitinase, PAL, PO, PPO and accumulation of phenols (Meena et al., 2000). Umamaheswari et al. (2009) investigated that watermelon plants pre-treated with bioagents exhibited higher activity of PAL, PO, PPO, $\beta$-1-3-glucanase as well as accumulation of phenol upon challenge inoculation with the pathogen.

In the present study, the production of defense related enzymes were examined in attempts to determine their role in resistance reactions to infection, induced by PGPR treatment. Our results 
clearly showed the increased synthesis of defense enzymes like PAL, POX, and PPO in two PGPR (SE34 and GBO3) treated rice plants after challenge inoculation with pathogen. The increased activities of the defense related enzymes in the PGPR treated rice plants may play either a direct or an indirect role in the suppression of pathogen development in the host ultimately protecting the plants from pathogenic microorganism.

Both PAL and POX play important roles in biosynthesis of phenolics, phytoalexins and lignin, the three key factors responsible for disease resistance (Daayf et al., 1997). Enhanced PAL and POX activity was reported by Ramamoorthy et al. (2002) in tomato infected by Fusarium oxysporum Schlecht. emend. Snyder and Hansen and Pythium upon treatment with P. fluorescens. PAL catalyses the conversion of phenylalanine to trans-cinnamic acid, a key intermediate in the synthesis of salicylic acid (Ryals et al., 1996). In the present study, increased activity of PAL and POX was recorded in rice seedlings grown from seeds treated with B. pumilus SE34 and B. subtilis GBO3 after challenge inoculation with the pathogen.

PPO is a copper containing enzyme, which oxidizes phenolics to highly toxic quinines and is involved in the terminal oxidation of diseased plant tissue, and which is attributed for its role in disease resistance (Kosuge, 1969). Involvement of PPO in ISR mediated by PGPR in cucumber has been demonstrated by Chen et al. (2000). Similarly to other enzymes, PPO activity was induced by two Bacillus strains against the challenged pathogen. Radjacommare (2000) reported that $P$. fluorescens Pf1 induced the activities of PPO in rice against Rhizoctonia solani.

Early and increased activity of defense enzymes, phenylalanine ammonia-lyase, peroxidase and polyphenol oxidase leads to disease suppression in SE34 and GBO3 treated rice plants in response to invasion by Xoo. The application of these rhizobacteria as seed treatments could prove to be a beneficial component of integrated pest management. These bacteria, apart from their action against bacterial leaf blight pathogen, are good growth promoters, and are able to induce systemic resistance in rice plants, which is an added advantage for practical agricultural system. It is evident that rhizobacteria could possibly serve as ecofriendly and sustainable alternatives to the hazardous chemicals used for growth promotion and management of crop diseases.

\section{References}

Agarwal, P.C., Mortensen, C.N., Mathur, S.B., 1989. Seed-borne diseases and seed health testing of rice. Technical Bulletin No. 3/Phytopathological Papers No. 30 Danish Government Institute of Seed Pathology for Developing Countries and CAB International Mycological Institute (DK/GB).

Babu, M.R., Sajeena, A., Vijaya Samundeeswari, A., Sreedhar, A., Vidhyasekaran, P., Reddy, M.S., 2003. Induction of bacterial leaf blight resistance in rice by treatment with acibenzolar-S-methyl. Annals of Applied Biology 143, 333-340.

Bai, Y.X., Zhou, X., Smith, D.L., 2003. Enhanced Soybean plant growth resulting from coinoculation of Bacillus strains with Bradyrhizobium japonicum. Crop Science 43, 1774-1781.

Baki, A.A., Anderson, J.D., 1973. Vigor determination in soybean seed by multiple criteria. Crop Science 13, 630-633.

Becker, G.J., Conrath, U., 2007. Priming for stress resistance; from the lab to field Current Opinion in Plant Biology 10, 425-431.

Biswas, J.C., Ladha, J.K., Dazzo, F.B., Yanni, Y.G., Rolfe, B.G., 2000. Rhizobial inoculation influences seedling vigor and yield of rice. Agronomy Journal 92 880-886.

Bostock, R.M., 2005. Signal crosstalk and induced resistance. straddling the line between cost and benefit. Annual Review of Phytopathology 43, 545-580.

Bowen, G.D., Rovira, A.D., 1999. The rhizosphere and its management to improve plant growth. Advances in Agronomy 66, 1-102.

Chen, C., Belanger, R.R., Benhamou, N., Paulitz, T.C., 2000. Defense enzymes induced in cucumber roots by treatment with Plant Growth Promoting Rhizobacteria (PGPR) and Pythium aphanidermatum. Physiological and Molecular Plant Pathology 56, 13-23.

Choong-Min, R., Murphy, J.F., Reddy, M.S., Kloepper, J.W., 2007. A two-strain mixture of rhizobacteria elicits induction of systemic resistance against Pseudomonas syringae and Cucumber mosaic virus coupled to promotion of plant growth on Arabidopsis thaliana. World Journal of Microbiology and Biotechnology 17, 280-286.
Conrath, U., Beckers, G.J.M., Flors, V., Garcia-Agustin, P., Jakab, G., Mauch, F., Newman, , Pieterse, M.A., Poinssot, C.M.J., Pozo, M.J., 2006. Priming: getting ready for battle. Molecular Plant-Microbe Interactions 19, 1062-1071.

Daayf, F., Bel-Rhlid, R., Belanger, R.R., 1997. Methyl ester of p-coumaric acid: a phytoalexin-like compound from long English cucumber leaves. Journal of Chemical Ecology 23, 1517-1526.

De-Vleesschauwer, D., Djavaheri, M., Peter, A.H.M., Bakker, Hofte.M., 2008. Pseudomonas fluorescens WCS374r-induced systemic resistance in rice against Magnaporthe oryzae is based on Pseudobactin-mediated priming for a salicylic acid-repressible multifaceted defense response. Plant Physiology 148, 19962012.

De-Vleesschauwer, D., Chernin, Leonid., Hofte, Monica., 2009. Differential effectiveness of Serratia plymuthica IC1270-induced systemic resistance against hemibiotropic and necrotrophic leaf pathogens in rice. Molecular Plant-Microbe Interactions 19, 1406-1419.

Di, M., Ye, H.Z., Schaad, N.W., Roth, D.A., 1991. Selective recovery of Xanthomonas spp. from rice seeds. Phytopathology 81, 1358-1363.

Gnanamanickam, S.S., Shigaki, T., Medalla, E.S., Mew, T.W., Alvarez, A.M., 1994. Problems in detection of Xanthomonas oryzae pv. Oryzae in rice seed and potential for improvement using monoclonal antibodies. Plant Disease 78, 173178.

Hammerschmidt, R., Nuckels, E.M., Kuc, J., 1982. Association of enhanced peroxidase activity with induced systemic resistance of cucumber to Colletotrichum lagenarium. Physiology and Pathology 20, 73-82.

Herman, M.A.B., Nault, B.A., Smart, C.D., 2008. Effects of plant growth promoting rhizobacteria on bell pepper production and green peach aphid infestations in New York. Crop Protection 27, 996-1002.

International Rules for Seed Testing, 2003. Proceedings of the International Seed Testing Association, International Rules for Seed Testing. Seed Science and Technology 21, 25-30.

Jayraj, J., Yi, H., Liang, G.H., Muthukrishan, S., Velazhahan, R., 2004. Foliar application of Bacillus subtilis AUBS1 reduces sheath blight and triggers defense mechanisms in rice. Journal of Plant Disease Protection 111, 115-125.

Jetiyanon, K., Kloepper, J.W., 2002. Mixtures of plant growth promoting rhizobacteria for induction of systemic resistance against multiple plant diseases. Biological Control 24, 285-291.

Kauffman, H.E., Reddy, A.P.K., Hsien, S.P.Y., Merca, S.D., 1973. An improved technique for evaluating resistance of rice varieties to Xanthomonas oryzae. Plant Disease Reporter 57, 537-541.

Kim, M.S., Kim, Y.C., Cho, B.H., 2004. Gene expression analysis in cucumber leaves primed by root colonization with Pseudomonas chlororaphis 06 upon challengeinoculation with Corynespora cassiicola. Plant Biology 6, 105-108.

Kloepper, J.W., 1993. Plant growth promoting rhizobacteria as biological agents. In: Metting, F.B., Jr. (Ed.), Soil Microbial Ecology Applications in Agricultural and Environmental Management. Marcel Dekker, New York, USA, pp. 254274.

Kloepper, J.W., Rodriguez-Kabana, R., Zehnder, G.W., Murphy, Jf., Sikora, E., Fernandez, C., 1999. Plant root-bacterial interactions in biological control of soil-borne diseases and potential extension to systemic and foliar diseases. Australasian Plant Pathology 28, 21-26.

Kloepper, J.W., Ryu, C.M., Zhang, S., 2004. Induced systemic resistance and promotion of plant growth by Bacillus spp. Phytopathology 94, 1259-1266.

Kosuge, T., 1969. The role of phenolics in host response to infection. Annual Review of Phytopathology 7, 195-222.

Kumari, V., Srivastava, J.S., 1999. Molecular and biochemical aspects of rhizobacterial ecology with special emphasis on biological control. World Journal of Microbiology and Biotechnology 15, 535-543.

Lalande, R., Bissonnette, N., Coutlee, D., Autoun, H., 1989. Identification of rhizobacteria from maize and determination of their plant-growth promoting potential. Plant and Soil 115, 7-11.

Liu, L., Kloepper, J.W., Tuzun, S., 1995. Induction of systemic resistance in cucumber by plant growth promoting rhizobacteria: duration of protection and effect of host resistance on protection and root colonization. Phytopathology 85, 10641068.

Lowry, O.H., Rosebrough, N.J., Farr, A.L., Randall, R.J., 1951. Protein measurement with the Folin phenol reagent. Journal of Biological Chemistry 193, 265-275.

Mayer, A.M., Harel, E., Shaul, R.B., 1965. Assay of catechol oxidase, a critical comparison methods. Phytochemistry 5, 783-789.

Meena, B., Ramamoorthy, V., Marimuthu, T., Velazhahan, R., 2000. Pseudomonas fluorescens in systemic resistance against late leaf spot of groundnut. Journal of Mycology and Plant Pathology 30, 151-158.

Mew, T.W., 1987. Current status and future prospects of research on bacterial leaf blight resistance in rice. Annual Review of Phytopathology 25, 359-382.

Mew, T.W., Leung, H., Savary, S., Cruz, C.M.V., Leach, J.E., 2004. Looking ahead in rice disease research and management. Critical Reviews in Plant Science 23, 103127.

Mortensen, C.N., 2005. Detection of Xanthomonas oryzae pv. oryzae from rice seeds by liquid assay. In: Seed Health Testing for Bacterial Pathogens. Danish Seed Health Centre for developing countries, Thorvaldsensvej 40, DK-1871, Frederiksberg C, Copenhagen, Denmark, pp. 65-68.

Murphy, J.F., Zehnder, G.W., Schuster, D.J., Sikora, E.J., Polstan, J.E., Kloepper, J.W., 2000. Plant growth-promoting rhizobacteria mediated protection in tomato against Tomato mottle virus. Plant Disease 84, 779-784.

Murphy, J.F., Reddy, M.S., Choong-Min, R., Kloepper, J.W., Li, R., 2003. Rhizobacteria mediated growth promotion of tomato leads to protection against cucumber mosaic virus. Phytopathology 93, 1301-1307. 
Mustafa, M., Yesim, A., Ozden, C., 2008. Biological control of Bacterial spot disease of pepper with Bacillus strains. Turkish Journal of Agriculture and Forestry 32, 381-390.

Nandakumar, R., Babu, S., Viswanathan, R., Raguchander, T., Samiyappan, R., 2001. Induction of systemic resistance in rice against sheath blight disease by Pseudomonas fluorescens. Soil Biology and Biochemistry 33, 603-612.

Nayaka, C.S., Shankar, U.A.C., Reddy, M.S., Niranjana, S.R., Prakash, H.S., Shetty, H.S., Mortensen, C.N., 2009. Control of Fusarium verticillioides causing ear rot of maize by Pseudomonas fluorescens. Pest Management Science 65, 769-775.

Nelson, L.M., 2004. Plant Growth Promoting Rhizobacteria (PGPR): prospects for new inoculants. Crop Management. doi:10.1094/CM-2004-0301-05-RV.

Niranjan-Raj, S., Chaluvaraju, G., Amruthesh, K.N., Shetty, H.S., Reddy, M.S., Kloepper, J.W., 2003a. Induction of growth promotion and resistance against downy mildew on pearl millet (Pennisetum glaucum) by rhizobacteria. Plant Disease 87, 380-384.

Niranjan-Raj, S., Deepak, S.A., Basavaraju, P., Shetty, H.S., Reddy, M.S., Kloepper, J.W., 2003b. Comparative performance of formulations of plant growth promoting rhizobacteria in growth promotion and suppression of downy mildew in pearl millet. Crop Protection 22, 579-588.

Raajimakers, J.M., Vlami, M., De Souza, J.T., 2002. Antibiotic production by bacterial biocontrol agents. Antonie van Leeuwenhoek 81, 537-547.

Radjacommare, R., 2000. Pseudomonas fluorescens mediated systemic resistance in rice sheath blight disease and leaf folder insect. M.Sc., (Ag.) Thesis, Tamil Nadu Agriculture University, Coimbatore, India. pp. 122.

Raju, N.S., Niranjana, S.R., Janardhana, G.R., Prakash, H.S., Shetty, H.S., Mathur, S.B., 1999. Improvement of seed quality and field emergence of Fusarium moniliforme infected sorghum seeds using biological agents. Journal of Science of Food and Agriculture 79, 206-212.

Ramamoorthy, V., Viswanathan, R., Raghuchander, T., Prakashan, V., Samiyappan, R., 2001. Induction of systemic resistance by plant growth promoting rhizobacteria in crop plants against pests and diseases. Crop Protection 20, 1-11.

Ramamoorthy, V., Raguchander, T., Samiyappan, R., 2002. Enhancing resistance of tomato and hot pepper to phythium diseases by seed treatment with fluorescent Pseudomonas. European Journal of Plant Pathology 108, 429-441.

Raupach, G.S., Kloepper, J.W., 2000. Biocontrol of cucumber diseases in the field by plant growth-promoting rhizobacteria with and without methyl bromide fumigation. Plant Disease 84, 1073-1075.

Reddy, A.P.K., 1980. Report on bacterial leaf blight epidemic of rice in Punjab. All India Coordinated Rice Improvement Project, Rajendranagar, Hyderabad, India, p. 1-30.

Ross, W.W., Sederoff, R.R., 1992. Phenylalanine ammonia lyase from loblolly Pine: Purification of the enzyme and isolation of complementary DNA clones. Plant Physiology 98, 380-386.

Ryals, J.A., Neuenschwander, U.H., Willits, M.G., Molina, A., Steiner, H.Y., Hunt, M.D., 1996. Systemic acquired resistance. Plant Cell 8, 1809-1819.
Ryu, C.M., Hu, C.H., Reddy, M.S., Kloepper, J.W., 2003. Different signaling pathways of induced resistance by rhizobacteria in Arabidopsis thaliana against two pathovars of Pseudomonas syringae. New Phytologist 160, 143-420.

Ryu, C.M., Farag, M.A., Hu, C.H., Reddy, M.S., Kloepper, J.W., Pare, P.W., 2004 Bacterial volatiles induce systemic resistance in Arabidopsis. Plant Physiology 134, 1017-1026.

Sakthivel, N., Mortensen, C.N., Mathur, S.B., 2001. Detection of Xanthomonas oryzae pv. Oryzae in artificially and naturally infected rice seeds and plants by molecular techniques. Applied Microbiology and Biotechnology 56, 435-441.

Saravanakumar, D., Vijayakumar, C., Kumar, N., Samiyappan, R., 2007. PGPRinduced defense responses in the tea plant against blister blight disease. Crop Protection 26, 556-565.

Schneider, S., Ullrich, W.R., 1994. Differential induction of resistance and enhanced enzyme activities in cucumber and tobacoo caused by treatment with abiotic and biotic inducers. Physiological and Molecular Plant Pathology 45, 291-304

Silo-Suh, L.A., Lethbridge, B.J., Raffle, S.J., He, H., Clardy, J., Handlesman, J., 1994 Biological activities of two fungistatic antibiotics produced by Bacillus cereus UW 85. Applied and Environmental Microbiology 60, 2023-2030.

Someya, N., Nakajima, M., Watanabe, K., Hibi, T., Akutsu, K., 2005. Potential of Serratia marcescens strain B2 for biological control of rice sheath blight. Biocontrol Science and Technology 15, 105-109.

Thompson, D.C., 1996. Evaluations of bacterial antagonist for reduction of summer patch symptoms in Kentucky blue grass. Plant Disease 80, 856-862.

Tjamos, S.E., Flemetakis, E., Paplomatas, E.J., Katinakis, P., 2005. Induction of resistance to verticillium dahliae in Arabidopsis thaliana by the biocontrol agent K-165 and pathogenesis-related proteins gene expression. Molecular Plant-Microbe Interactions 18, 555-561.

Udayashankar, A.C., Nayaka, C.S., Niranjan-Raj, S., Kumar, B.H., Reddy, M.S., Niranjana, S.R., Prakash, H.S., 2009. Rhizobacteria mediated resistance agains Bean common mosaic virus strain blackeye cowpea mosaic in cowpea. Pest Management Science 65, 1059-1064.

Umamaheswari, C., Sankaralingam, A., Nallathambi, P., 2009. Induced systemic resistance in watermelon by biocontrol agents against Alternaria alternate. Archives of Phytopathology and Plant Protection 42, 1187-1195.

Van Loon, L.C., Bakker, P.A.H.M., Pieterse, C.M.J., 1998. Systemic resistance induced by rhizosphere bacteria. Annual Review of Phytopathology 36, 453-483.

Vidhyasekaran, P., Kamala, N., Ramanathan, A., Rajappan, K., Paranidharan, V., Velazhahan, R., 2001. Induction of systemic resistance by Pseudomonas fluorescens Pf1 against Xanthomonas oryzae pv. Oryzae in rice leaves Phytoparasitica 29, 155-166.

Viraktamath, B.C., Rani, N.S., 2008. Pivotal position achieved by combination of factors. ICAR Hyderabad. The Hindu Survey of Indian Agriculture 2, 22-24.

Zhang, S., Reddy, M.S., Kloepper, J.W., 2004. Tobacco growth enhancement and blue mold disease protection by rhizobacteria, relationship between plant growthpromotion and systemic disease protection by PGPR strain 90-166. Plant and Soil 262, 277-288. 